Mobility within the children's workforce: evidence for a new policy?

June Statham (author for further contact)

Reader in Education and Family Support

Thomas Coram Research Unit

Institute of Education, University of London

27/28 Woburn Square

London WC1H OAA

j.statham@ioe.ac.uk

Julia Brannen

Professor in the Sociology of the Family

Thomas Coram Research Unit

Ann Mooney

Senior Research Officer

Thomas Coram Research Unit 


\section{Mobility within the children's workforce: evidence for a new policy?}

\section{Abstract}

This article presents findings from a three-year government-funded study of the work and family lives of four important groups within the children's workforce in England: residential social workers in children's homes, family support workers, foster carers and community childminders. The study used a combination of quantitative and qualitative methods, including biographical narrative interviews. The policy context of the Children's Workforce Strategy is discussed, focusing particularly on the government's aim to develop greater integration between different types of work with children and the creation of a more flexible children's workforce. The article then draws together findings from the study to argue that although the planned integrated qualifications framework may assist mobility within the children's workforce, other factors also need to be taken into account. The choice to engage in particular types of childcare work is often linked to factors such as life stage, preferred age of child, preferred working environment and the worker's own background and needs. This suggests the need for more targeted recruitment, matching people to type of work, and for more attention to be paid to the connections between work and family life. The study does provide some evidence of transferable skills and movement over time between types of work with children, and demonstrates the importance of seeing the life-course as presenting opportunities for childcare employment rather than being an obstacle.

\section{Key words}

Children's workforce, vulnerable children, recruitment, biographical narrative, social care, interagency working.

\section{Acknowledgements}

This research was originally commissioned by the Department of Health and became the responsibility of the Department for Education and Skills when children's social care was transferred between departments. The views expressed in this article are those of the authors and do not necessarily reflect those of either Department. 


\section{Introduction}

The children's workforce has received considerable attention from central government in recent years. This is partly as a result of childcare scandals which have focused attention on failures among those working with vulnerable children (e.g. Laming, 2003), and partly in response to long-standing problems of recruitment and retention in this field (Eborall, 2005; Children's Workforce Development Council, 2006). The Every Child Matters: Change for Children programme (HM Government, 2003) has made 'workforce reform' a key area for action. The creation of a Children's Workforce Development Council in 2005 and the publication of a Children's Workforce Strategy, which aims to 'build a world-class workforce for children and young people' (HM Government, 2005a), have taken this work forward.

The 'children's workforce' stretches across many professional and organizational boundaries, but the focus in this paper is on four particular groups who provide 'social care' services for vulnerable children or young people and their families:

- residential social workers working in children's homes,

- family support workers, working either in social work teams or family centres,

- foster carers working either for a local authority or an independent foster agency,

- childminders working with children placed and paid for by social services, often known as 'community' or 'sponsored' childminders.

A key aspect of the modernization agenda for the children's workforce is to develop greater integration between the different types of work with children, and greater flexibility for workers to move within and between them. The importance of developing an integrated workforce strategy for those providing services to vulnerable children and their families was acknowledged in a report published soon after the Every Child Matters Green Paper, which recommended that 'the future strategy needs to identify a map of the whole workforce and career pathways to ensure that focus is on how services need to be delivered in the new integrated approach, rather than on specific functions and roles' (Topss England 2003, p54). 
One element of this workforce strategy has been to define a 'common core' of skills and knowledge intended to apply to all those working with children and young people, whatever their level, occupation or setting (HM Government, 2005b). The six main areas are effective communication, knowledge of children and young people's development, safeguarding and promoting welfare, supporting transitions, multi-agency working and information sharing. The Common Core is already being used by some providers to inform their training delivery (Harrison, 2006). It will form part of an integrated qualifications framework for the children's workforce, to be in place by 2010 , that is intended to facilitate movement across different work streams and job roles. Specialist, job-specific skills and understandings will still be required for different roles, but the aim is that a shared body of skills will support the development of a more integrated workforce:

'We need to identify what is common about the work we do together and create a flexible workforce that wants to stay working with children, one that sees a longterm career in the workforce - a career that could mean doing different types of work over time but building on skills as social care workers and social workers' (Harrison, 2006, p17-18)

A large scale survey, carried out for the DfES in 2005 to test how far the Every Child Matters agenda was affecting ideas and practice, asked a wide range of workers with children and young people if they agreed or disagreed with a statement that "it is difficult to move between different types of jobs across different children's and young people's services" (Deakin and Kelly, 2006). Respondents, who included foster carers, residential care workers and childminders, were more likely to disagree (45\%) than agree (38\%) that it was difficult to move, which suggests that there is a perception, at least, of flexibility within work with children.

Previous research has also provided some objective evidence of workers moving between care sectors and types of care work, possibly in search of better working conditions, particularly better remuneration. For example, one study found that two thirds of day 
nursery staff had moved within the childcare and early years field (Cameron et al., 2001). A survey of childminders who had ceased childminding reported that one third had moved to other childcare-related jobs, and a further third thought they might do so in the future (Mooney et al., 2001). Almost a quarter (23\%) of all fosters carers in another survey were working or had worked in a child-related occupation (Bebbington and Miles, 1990), and a study of carers offering short breaks to families with a child in need found that over two thirds had extensive previous experience of working with children (Aldgate and Bradley, 1999). Often, however, information is collected about turnover but not about what leavers go on to do. For example, the most recent social care workforce survey collected information on the destinations of leavers and the origins of starters, but for field social workers only (Local Government Association, 2006).

Despite policies to promote flexibility among the children's workforce, there has been very little research examining the extent to which childcare workers might want to move between different types of care work, nor how this might relate to their stage in the life course or how they make sense of their trajectories over time. Different types of work may prove attractive to people at different times of their lives. For example, childminding tends to be undertaken by women when their own children are young (Mooney et al., 2001) whilst foster care may be started when carers and their children are older. Indeed, the ageing of the foster care workforce combined with difficulties in recruiting new carers has created concerns over the ability of councils to offer children a choice of appropriate placements (Fostering Network, 2004; Morgan, 2005). Within the social care workforce, those working in children's homes tend to be younger than average, and this sector of the workforce has the highest proportion of staff aged under $40(45 \%)$ and the lowest proportion aged over 50 (25\%) (Local Government Association, 2006).

A report by the Children's Workforce Development Council in 2006 concluded that the majority of the children's workforce was not yet ready to 'respond quickly and productively to a modernisation process' (CWDC 2006, p4) and recommended that the Children's Workforce Network develop strategies 'to encourage greater workforce mobility and remove artificial barriers to entry and exit'. The report suggests that the main barrier to moving between jobs is the specific training and qualification 
requirements that each requires, and the plethora of different qualifications and awarding bodies operating in the sector. Whilst training and qualifications are undoubtedly important, we focus in this article on other, more subtle factors that might affect workers' ability and willingness to move between different types of childcare work. To do so we draw on selected findings from a three-year government-funded study which, uniquely, compared personal accounts of employment histories, current experiences and future intentions from four different types of worker with vulnerable children in England. The full results of the study are reported elsewhere (Brannen et al., 2007 forthcoming).

\section{The study}

The selection of the four worker types (residential social workers, family support workers, foster carers and community childminders) was guided by both theoretical and policy considerations. They provided a number of contrasts, for example in the site of care, the likely life course stage of the carer and the employment status of the worker. All are central to the provision of services for vulnerable or disadvantaged children and their families, yet at least two of the groups (family support workers and community childminders) have received very little attention from researchers. Their work shares some common features, for example relatively low rates of pay and - until recently at least - few requirements for formal qualifications (CWDC, 2006). However, there is also considerable diversity between the four groups, on a number of dimensions which may affect the ease with which workers move between different types of child care work. These include the age group with whom the carer works, the extent of the child's needs, whether the child is looked after or supported within their own family of origin, whether the work involves parents as well as children or young people, the location where care work takes place, and the time period over which care is provided (Table 1).

[Insert Table 1 around here]

The research project, which was undertaken for the Department for Education and Skills by the Thomas Coram Research Unit, adopted a multi-method approach that combined both quantitative and qualitative methods, including use of biographical-narrative 
interviews to allow childcare workers to tell their own stories about their work and family lives (Wengraf, 2001). Most of the fieldwork was undertaken in two local authorities: a London borough and a large county council in the South of England, although additional authorities were recruited in order to ensure sufficient numbers of family support workers and community childminders.

Two surveys were conducted a year apart (early 2004 and early 2005) with the same set of respondents, in which most questions were structured and pre-coded. The first was a postal survey, which included questions about intentions to stay in or leave the work. The questionnaire was distributed by local authority or independent agency managers to all childcare workers in the selected groups, and produced a response rate of $56 \%$. The 305 childcare workers who responded were equitably distributed between the four occupational groups. Respondents from the postal survey who agreed to further contact (almost two thirds) were followed up one year later, with a telephone interview addressing actual loss from and movement within the childcare workforce and the reasons for this. Twenty four biographical case study interviews were also undertaken during the intervening year, involving six workers from each of the four groups. These provided a wealth of data on how and why individual care workers entered and developed their employment careers within the context of their whole lives. Finally, a series of semistructured interviews was conducted with 16 senior and middle managers of the workers across the public, private and voluntary sectors. These explored policy and practice concerning recruitment, retention, training and support, including any policies to enable or encourage workers to develop their careers and move between different types of care work with vulnerable children. In the remainder of this paper, we draw together these different sources of data to consider how far they support current policies to develop a more flexible, integrated children's workforce in England. 


\section{Findings}

\section{Type of work and life course phase}

Deciding to enter childcare work was often part of a complex chain of events and contexts in which people lived their lives. The in-depth case studies identified five main routes into childcare work:

- a particular life-course phase (such as having young children and needing to combine family responsibilities with care work in the home);

- significant life events such as bereavement or divorce or difficult experiences with their own children;

- voluntary work as a route out of full-time motherhood into childcare work;

- a recommendation from a professional, family member or friend; or

- serendipity - just being in the right place at the right time, such as when a person worked in a non-care occupation but was located in a social services context and was attracted to work with children.

Of particular relevance when considering flexibility across the children's workforce is the extent to which there was a link between life course phase and entering a particular type of childcare work. Evidence from the postal survey of 305 childcare workers supported such a link. Different groups of workers reported starting their occupation at different ages. In contrast to residential social workers and community childminders, foster carers were more likely to be aged 40 or over when they started fostering, with family support workers following behind them in age terms (see Table 2). The residential social workers in the survey were least likely to be parents, while community childminders were most likely to have young children.

[Insert Table 2 around here]

On the basis of the biographical interviews, it seemed that the start of a career in child care was prompted by a particular life course phase in the majority $(17 / 24)$ of cases. A 
few carers went into childcare work straight from school - either via a training course or directly into care work. For others, the entry into care work was a strategy for managing work and family life during the transition to parenthood. Typically women from working class backgrounds, as most of the care workers were, had few qualifications. Becoming a mother with a young child constrained what they were able to do in terms of paid work, especially where they had little labour market experience and could not afford to pay for childcare. Thus some women opted to become a childminder or foster carer, working in their homes while bringing up their own children. In other cases, the entry of their own children into school or secondary school, or their older children leaving home signalled the decision to move into the labour market and into care work outside the home. This later entry into (childcare) work was common among women from older cohorts.

\section{Preference for working with particular groups}

Personal histories and preferences also influenced decisions to enter a particular type of childcare work. Many of the case-study workers expressed a strong preference for working with a particular client group, such as children of a certain age, gender or level

of need, and it seemed that this would restrict their willingness to move between types of care work. For example residential social worker A had started her care work in an army crèche but had found after volunteering in a youth club that she much preferred the challenge of working with teenagers. This had led her into working in a children's home:

The little uns are good, it's nice to see them, but there's only so much you can do with the little ones and that. Where with the older ones there's a lot more you can do with them.

Community childminders, on the other hand, frequently referred to their enjoyment of working with babies and young children. Childminder O, who had an 18 year old son as well as a 5 year old daughter, definitely did not want to work with teenagers: 'they become difficult then and (pause) and just, they're so headstrong'. 
$\mathrm{C}$, a foster carer, preferred placements of boys to girls, partly because of her concerns about the impact of self-harming or sexually active behaviour on her own fifteen-year-old daughter, but also because she had experienced more success with boys and thought that her rural location was less suitable for girls 'who have got to be in town every five minutes'. She felt that she had 'done my baby bit. I would rather have the older child. And that's where my success rate has been'. Family support worker M was likewise drawn to working with difficult male adolescents, whom she regarded as ' $m y$ forte'. She said that she was especially able to relate to this group because of her experiences with her own sons, and relished the challenge that this particular client group provided.

Other care workers had started off providing a particular kind of care, such as short-term foster placements for teenagers, but then realized that this did not suit their family circumstances. $\mathrm{G}$ and her husband had begun their fostering career with an independent agency providing emergency placements when their own children were young, but after four such placements had failed, they decided instead to foster a twelve year old girl with an autistic spectrum disorder on a long-term basis. They had found it difficult to look after volatile teenagers while bringing up their own small children.

If you're looking after little children who get up at 6 o'clock in the morning and you've got grown up children that are sort of being very angry and running away and doing stupid things, it just actually puts too much pressure.

The above examples suggest that government policy to encourage greater movement within the children's workforce may have limited success, when particular types of work are chosen due to personal circumstances and preferences. This was further supported by analysis of case study workers' responses to vignettes depicting movement between types of childcare work, and to a question about the notion of a 'core worker' able to work in a variety of settings with vulnerable children and young people. There was general acceptance among the case study interviewees of the value of a common core of knowledge for all those working with children, and support in principle for the idea of greater flexibility across different types of childcare work. 
However, many of those interviewed did not themselves want to be doing a different type of childcare work. Their responses when presented with specific situations in the vignettes tended to emphasise the differences rather than the similarities between the four types of work, such as the commitment needed to take on a foster child, or the different knowledge needed by someone caring for babies and young children compared to someone supporting young people or care leavers. Residential social worker A, for example, thought that the age differences of the children cared for would make it difficult to move between residential care (her current job) and community childminding, since residential care was mostly with older children and 'early years is a totally different category'. She had thought about fostering, but would not want to provide continuous care since 'with residential work you leave it and you come home, your work's done, it's one of those [jobs] you can turn off from'. Three of the six sponsored childminders interviewed in depth had also considered fostering, but had not pursued this because they feared that the emotional stress of parting from a child that had become a part of their life would be too difficult.

\section{Commitment to work with children}

On the other hand, our study did provide evidence of considerable flexibility and movement over time between types of work with children, especially in work with children within a similar age range. Among respondents to the Postal Survey, over half $(52 \%)$ had moved to their current post from another type of care work, sometimes with adults but more often with children and young people. More than three quarters $(78 \%)$ had previous childcare experience in a different setting, such as pre-school playgroup worker, classroom assistant, nursery nurse or youth worker. Family support workers appeared to have the greatest variety of experience, with half having worked in three or more different childcare roles. Some of this flexibility was life course related, and reflected progression of care workers' careers as mothers or as workers.

Also providing support for the notion of a 'career' in work with children was a strong commitment to working with children and families, particularly those that were vulnerable or needed additional support. This emerged as a consistent theme throughout 
this study. It was evident in the case study interviews, where workers spoke about the satisfaction they obtained from feeling they could make a difference to children's lives, and in the survey data where few wanted to move away from working with children, even if they also expressed dissatisfaction with various aspects of the work.

In the Time One postal survey, for example, childcare workers were asked whether they saw their future in their current type of work as short- or long-term (five years or more), how long they thought they would stay, how often they thought about giving up, and whether they would continue in care work with children if they left. The results indicated a high level of commitment to work with vulnerable children, alongside some uncertainty about future plans. Almost two thirds described their future in the work as long-term and more than four in ten thought they would still be doing the same type of work in five years, while around a third did not know. Only $11 \%$ of childcare workers had 'often' thought of giving up and almost a third said that they had done so 'hardly ever or not at all'. When asked what they would do if they did leave their current job, the majority of respondents either did not want to stop what they were doing $(21 \%)$ or would take another job working directly with children (40\%). Most of the rest thought that they would retire, or did not know (Table 3).

[Insert Table 3 around here]

Approximately a year after completing the postal survey, follow-up telephone interviews were carried out with those respondents who had agreed to further contact, which was just under two thirds of the total. Excluding those who provided no contact details and those who were selected for case-study interviews, $87 \%$ of potential follow-up interviews were achieved, with 34 residential social workers, 36 family support workers, 35 community childminders and 24 foster carers (129 interviews in total). The great majority $(82 \%)$ were still in the same type of work a year later, although residential social workers were more likely than the other three groups to have moved on. Of the small number who had left, two thirds were still working with children or families. Three childminders were no longer offering local authority placements but were still providing childcare for working parents, and two family support workers had left to do a social work degree or 
diploma but were doing their placements in children's services. Two of the leavers had retired, four (who had all been working in children's homes) were still doing care work but with adults, and only one of those who had left had moved into a completely different area of work, in the music business.

Given that the majority of those who had moved to a different type of work in the year after the Postal Survey had remained in care work, it was not surprising to find that most of them believed that their previous job had provided them with skills that were useful in their current work. Patience, understanding children with difficult or challenging behaviour, communication and relationship skills were all mentioned as transferable between the different types of work, reflecting some of the competencies defined in the Common Core of Skills and Knowledge (HM Government 2005b).

When the leavers were asked about their future work plans, there was evidence of contextual and situational reasons for movement between different types of care work with children as well as movement in pursuit of career development. For example, a young woman who had left residential social work after a year to work in a private day nursery, was motivated by a sense of professional development and saw this work as a stepping stone to work in a primary school as a classroom assistant. But she also felt that in her mid-twenties she had been too young to cope with the emotionally, mentally and physically stressful work in a children's home. A family support worker who had just begun a social work degree hoped to work for a charity providing direct play therapy with abused children after she qualified. A childminder who had stopped accepting local authority placements intended to return to social work when her youngest child started school. Another community childminder had stopped this work to train to be a teacher, and a third was exploring the idea of fostering now that she had a larger house and her own children would soon leave home.

Continuing engagement with care work was also evident when childcare workers who were still in the same type of work at the time of the follow-up survey, but who had considered leaving during the previous year, were asked what they had considered doing instead. Over half (18/32) said they would still be working with children or young people, 
and most of the rest did not have particular plans or ideas. Residential social workers mentioned jobs such as care work in a children's hospice or with disabled children, social work with children (but not residential), and work in a respite children's home. Family support workers expressed a preference for jobs involving some kind of therapeutic or counseling work, such as play therapy, counseling abused children or psychotherapy. A quarter of childcare workers who had considered leaving $(8 / 32)$ had thought about moving into care work with adults instead, such as working with adults with learning disabilities or mental health needs. Only four were considering moving out of care work altogether, and three of these were residential social workers.

\section{Employer perspectives on workforce mobility}

Managers with responsibility for the four different groups of workers were asked about policy and practice within their organization concerning movement between types of work with children and young people. Overall, there was little evidence from these interviews that managers had yet developed strategies for encouraging flexibility across the children's workforce as a whole. This reflects the findings of a recent local government workforce survey, where for example only $22 \%$ of local authorities reported undertaking workforce planning for workers in children's homes, and just 9\% said that they were developing career pathways for this group (LGA, 2006).

In the current study, some initiatives were being developed for family support workers, who were seen as a crucial group in responding to the change agenda for children's services set in train by Every Child Matters. These initiatives included support for obtaining additional qualifications so family support workers could progress to children's social work, and new arrangements to spend part of their time working in different settings such as schools and doctors' surgeries or within different social work teams. Managers of all four types of worker described training and development opportunities to help workers progress within their current role, but little consideration appeared to have been given to how different roles might fit together, or to how horizontal as well as vertical progression within the children's workforce might be encouraged, perhaps as a 
way of helping workers to manage work/family responsibilities at different stages of their lives.

A number of managers were positive in principle about greater transferability between types of work with children and could see its relevance in the light of more integrated children's services. From the employers' perspective, reasons given for encouraging such flexibility included potential benefits to recruitment, and an improved and more efficient service. One manager, when describing how several experienced community childminders had recently moved on to other childcare work, described this as a 'good loss' which would promote the community childminding scheme in a wider field, and noted that 'every service needs people that develop'. It was suggested that experience of a variety of types of childcare work would result in 'a more rounded person in terms of professional skills' and hence a better service for children, as well as perhaps reducing burnout among staff.

However, other managers cited factors which they thought discouraged a policy of flexibility and movement within the children's workforce. One was worker preferences, which as we have seen also emerged as a factor discouraging mobility in the interviews with workers themselves. For example, there was a perception that foster carers often took up this work because they wanted home-based work and so would not be interested in other types of childcare work. A common theme in interviews with managers across all four types of worker was that there were two groups of unqualified workers: those who were keen to progress and possibly branch out into new areas, and those who wanted to remain as they were. The latter group could find encouragement to diversify or to acquire new qualifications threatening, and managers in both authorities where the role of family support workers was being extended noted that it was important not to devalue existing roles by creating new opportunities.

A second factor, cited especially by service managers, was a fear of either poaching or losing staff. Given the widely acknowledged difficulties in recruiting and retaining staff for care work with children, it is perhaps not surprising that some managers expressed a desire to 'hold on to their own', although it could be argued that the approach of the 
community childminder manager described above might be more effective in attracting and retaining staff in the longer term. Foster carers in particular were rarely mentioned as a possible source of recruits for other types of care work, which may reflect the priority given to retaining existing foster carers within the service. For example, one local authority fostering service manager explained that developing care careers for foster carers was not a priority: 'there's other issues that you need to look at before [looking at] what else they can offer or what jobs they can move on to'.

A third challenge perceived by managers to increased mobility among the children's workforce was structural factors such as the disparity in pay and conditions between different types of childcare work. The Human Resources manager in one local authority in the study, where workplace structures were beginning to be reviewed 'to make sure that we have the ability to progress people rather than [them] having to leave to be promoted', suggested that pay banding was a key issue in enabling cross-sector movement. If pay bands were made wider, he argued, people could be encouraged to move more easily between types of work with children without pay loss or change of salary scale. Another senior manager, from a different local authority, believed that the status differences between different types of work with children would also prove an obstacle to greater mobility. Although she said she would like to believe that a common core of qualifications would begin to break down these demarcations, she was not hopeful that this would happen.

\section{Conclusion}

The findings of this study suggest that the government's strategy to develop a more flexible, integrated children's workforce needs to go beyond constructing an integrated qualifications framework, important though this may be. In this article we have presented some evidence of transferable skills and movement between types of work with children - but also reasons why people choose certain types of work, for example their life stage, location, preferred age of child, and own personality or needs. Where this is the case, as when people with older or grown up children decide to foster children and to look after older age groups, or when a community childminder wants to look after young children 
when she has her own at home, recruitment needs to be targeted, matching people to type of work. More attention could be paid to the connections between individuals' work and family lives, and to the multiplicity of factors that influence decisions about entering and moving within - the children's workforce. Opportunities to gain first-hand experience of different types of childcare work could be a powerful way of encouraging workers to branch out into other types of work with children. This had been the case for a number of family support and residential social workers in our study, where placements undertaken as part of a social work degree or diploma had opened up possibilities that might not previously have been considered.

Increased flexibility and encouragement to develop 'careers' in work with children, for example by offering professional training, can increase opportunities and make the work more attractive and financially rewarded. However, care needs to be taken not to lose the existing strengths of the workforce. For example, we found cases of family support workers who felt undervalued because they did not choose to train in social work (a possibility for some) yet felt they were doing equally important and demanding work.

When childcare workers do move on, it is usually to another type of care work with children or young people. This finding provides support for policies to develop a more integrated children's workforce. Studies of recruitment and retention among childcare workers have tended to highlight the difficulties in attracting and keeping workers within a particular job. However, the fact that this movement is mostly within - rather than out of - the childcare workforce should perhaps be regarded as a strength rather than a problem, provided that it does not compromise continuity of care for individual children. In this study, local authority children's services managers were beginning to develop strategies to extend the role of certain groups who were seen as key to the remodeling agenda, such as family support workers. What was less in evidence was a broader consideration of the needs of the childcare workforce as a whole, and of ways in which career pathways could be developed horizontally as well as vertically between different types of work with children and young people. 


\section{References}

Aldgate J. and Bradley M. (1999) Supporting families through short-term fostering. London: The Stationery Office

Bebbington, A and Miles, J (1990) 'The supply of foster families for children in care', British Journal of Social Work, 20, 4, 283-3

Brannen, J., Statham, J., Mooney, A. and Brockmann, M. (2007, forthcoming) Coming to Care: the work and family lives of workers caring for vulnerable children Bristol: Policy Press

Cameron, C.; Owen, C. and Moss, P. (2001) Entry, Retention and Loss: A Study of Childcare Students and Workers. London: DfEE.

Children's Workforce Development Council (2006) Recruitment, retention and rewards in the children's workforce. http://www.cwdcouncil.org.uk/projects/rrr.htm

Deakin, G. and Kelly, G. (2006) Children's Workforce Research. DfES Research Report No. 716, www.dfes.gov.uk/research

Eborall, C. (2005) The State of the Social Care Workforce 2004. The second skills research and intelligence annual report. Leeds: Skills for Care

Fostering Network (2004) Shortage of foster carers reaches critical levels. Press release 24 August 2004. www.fostering.net/news

Harrison, A. (2006) The Children's Workforce Development Council and Residential Child Care Staff. National Centre for Excellence in Residential Child Care Conference proceedings. Issue 21, 17-19. www.ncb.org.uk/ncercc/20060428ncerccnewsletter.pdf

HM Government (2003) Every Child Matters. London: The Stationery Office HM Government (2005a) Children's Workforce Strategy. Nottingham: DfES HM Government (2005b) Common Core of Skills and Knowledge for the Children's Workforce. Nottingham: DfES

Laming, Lord (2003) The Victoria Climbié Inquiry Report. London: The Stationery Office

Local Government Association (2006) Adult, children and young people local authority social care workforce survey 2005. Report No. 36. Social Care Workforce Series www.lgar.local.gov.uk

Mooney A., Knight A., Moss P. and Owen C. (2001) Who Cares? Childminding in the 1990s Bristol: Policy Press 
Morgan R. (2005) Being Fostered: a national survey of foster children, foster carers and birth parents. London: CSCI

Topss England (2003) Integrated and Qualified: workforce development for effective delivery of services to vulnerable children and young people, and those who care for them. Leeds: Topss England

Wengraf, T. (2001) Qualitative Research Interviewing: Biographic narrative and semistructured methods. London: Sage 
Tables for Statham et al. Mobility within the children's workforce

Table 1 Dimensions of care work

\begin{tabular}{|lllll|}
\hline & $\begin{array}{l}\text { Residential } \\
\text { Social } \\
\text { Worker }\end{array}$ & $\begin{array}{l}\text { Family } \\
\text { Support } \\
\text { Worker }\end{array}$ & Foster Carer & $\begin{array}{l}\text { Community } \\
\text { Childminder }\end{array}$ \\
\hline $\begin{array}{l}\text { Age of child/ } \\
\text { client }\end{array}$ & $\begin{array}{l}\text { Mostly } \\
\text { adolescents }\end{array}$ & $\begin{array}{l}\text { Parents, young } \\
\text { children and } \\
\text { adolescents }\end{array}$ & $\begin{array}{l}\text { Young children } \\
\text { or adolescents }\end{array}$ & Young children \\
\hline $\begin{array}{l}\text { Child's level } \\
\text { of need/ } \\
\text { difficulty }\end{array}$ & High & Medium/high & Medium/high & Low/medium \\
\hline $\begin{array}{l}\text { Child's legal } \\
\text { status }\end{array}$ & $\begin{array}{l}\text { Looked } \\
\text { after }\end{array}$ & $\begin{array}{l}\text { With parents/in } \\
\text { the community }\end{array}$ & Looked after & With parents \\
\hline $\begin{array}{l}\text { Work with } \\
\text { parents too }\end{array}$ & Rarely & Yes & Some contact & Varies \\
\hline $\begin{array}{l}\text { Time spent } \\
\text { with client }\end{array}$ & $\begin{array}{l}\text { Fulltime } \\
\text { care but } \\
\text { provided on } \\
\text { shift basis }\end{array}$ & $\begin{array}{l}\text { Short task- } \\
\text { focused care }\end{array}$ & $\begin{array}{l}\text { Fulltime care } \\
\text { on 24/7 basis }\end{array}$ & $\begin{array}{l}\text { Daytime care, } \\
\text { occasionally } \\
\text { overnight or }\end{array}$ \\
& $\begin{array}{l}\text { Institution } \\
\text { (but 'home } \\
\text { like') }\end{array}$ & $\begin{array}{l}\text { Parent's home } \\
\text { or community } \\
\text { setting }\end{array}$ & Carer's home & Carer's home \\
\hline $\begin{array}{l}\text { Location of } \\
\text { care }\end{array}$ & $\begin{array}{l}\text { Employed } \\
\text { (public and } \\
\text { private } \\
\text { sector) }\end{array}$ & $\begin{array}{l}\text { Employed } \\
\text { (mostly public } \\
\text { sector) }\end{array}$ & $\begin{array}{l}\text { Paid an } \\
\text { allowance to } \\
\text { cover } \\
\text { expenses }\end{array}$ & Self employed \\
\hline $\begin{array}{l}\text { Worker's } \\
\text { employment } \\
\text { status }\end{array}$ & & & \\
\hline
\end{tabular}

Table 2 Age started in occupation by type of worker

\begin{tabular}{|c|c|c|c|c|c|c|c|c|c|c|}
\hline \multirow[t]{2}{*}{ Age in years } & \multicolumn{2}{|c|}{$\begin{array}{l}\text { Residential } \\
\text { Social Worker }\end{array}$} & \multicolumn{2}{|c|}{$\begin{array}{c}\text { Family Support } \\
\text { Worker }\end{array}$} & \multicolumn{2}{|c|}{ Foster Carer } & \multicolumn{2}{|c|}{$\begin{array}{l}\text { Community } \\
\text { Childminder }\end{array}$} & \multicolumn{2}{|c|}{ All } \\
\hline & $\mathrm{N}$ & $\%$ & $\mathrm{~N}$ & $\%$ & $\mathrm{~N}$ & $\%$ & $\mathrm{~N}$ & $\%$ & $\mathrm{~N}$ & $\%$ \\
\hline$<30$ & 44 & 55 & 17 & 21 & 5 & 7 & 18 & 29 & 84 & 28 \\
\hline $30-39$ & 20 & 25 & 30 & 37 & 25 & 35 & 33 & 53 & 108 & 37 \\
\hline $40-49$ & 13 & 16 & 28 & 34 & 33 & 46 & 10 & 16 & 84 & 28 \\
\hline $50+$ & 3 & 4 & 7 & 9 & 9 & 13 & 1 & 2 & 20 & 7 \\
\hline Total & 80 & & 82 & & 72 & & 62 & & 296 & \\
\hline
\end{tabular}


Table 3 What would do if left residential care, family support, foster care or childminding: postal survey

\begin{tabular}{|c|c|c|c|c|c|c|}
\hline & $\begin{array}{c}\text { Residential } \\
\text { Social } \\
\text { Worker } \\
\% \\
\end{array}$ & $\begin{array}{c}\text { Family } \\
\text { Support } \\
\text { Worker } \\
\%\end{array}$ & $\begin{array}{c}\text { Foster } \\
\text { Carer } \\
\% \\
\end{array}$ & $\begin{array}{c}\text { Community } \\
\text { Childminder } \\
\% \\
\end{array}$ & All & $\%$ \\
\hline Don't want to stop & 27 & 13 & 25 & 19 & 63 & 21 \\
\hline Another job with children & 45 & 43 & 28 & 44 & 121 & 40 \\
\hline Care work with adults & 6 & 2 & 11 & 6 & 19 & 6 \\
\hline $\begin{array}{l}\text { A job not related to care and/or } \\
\text { children }\end{array}$ & 2 & 4 & 10 & 6 & 16 & 5 \\
\hline Take a break from paid work & 2 & 2 & 3 & 3 & 8 & 3 \\
\hline Retire & 6. & 20 & 14 & 9 & 38 & 13 \\
\hline Don't know & 20 & 13 & 17 & 20 & 52 & 17 \\
\hline TOTAL & 82 & 84 & 72 & 64 & 302 & 100 \\
\hline
\end{tabular}

